жизни в стране. И многое зависит не только от государства, но и от сознания самого человека и гражданина.

$$
* * *
$$

1. Федеральный закон от 25.12.2008 № 273-Ф3 «О противодействии коррупции» [Электронный ресурс / К КонсультантПлюс: справ. правовая система.

URL.:http://www.consultant.ru/document/cons_doc_LAW_82959/

2. Мещеряков Д. В. Возникновение и развитие коррупции / Д. В. Мещеряков // Гуманитарные научные исследования - 2016, № 10 - С. 13.

3. Межведилов А. М., Бакулина Л. Т. Противодействие коррупции: учебное пособие / А. М. Межведилов, Л.Т. Бакулина, И. О. Антонов, М. В. Талан, Ю. В. Виноградова, А. Д. Гильфанова. Казань: Изд-во Казан. ун-та, 2016. - С. 143.

4. Качкина Т. Б., Качкин А. В. Коррупция и основные элементы стратегии противодействия ей: Учебное пособие. / Т. Б. Качкина, А. В. Качкин - Ульяновск: ОАО «Областная типография «Печатный двор». 2010. - С. 51

\title{
Богинич А.A. \\ К вопросу о понятии «специальные знания» в российском уголовном процессе и криминалистике применительно к делам о незаконном обороте наркотических средств и психотропных веществ
}

Кубанский государственный аграрный университет имени И.Т. Трубилина (Россия, Краснодар)

doi: $10.18411 / 1 j-07-2021-75$

\section{Аннотация}

Рост криминальной преступности в Российской Федерации - это, на сегодняшний день, явление прогрессивное, требующее определённого механизма противодействия, выражающегося в мобилизации всех сил и средств со стороны правоохранительных и вспомогающих органов. Выявление, пресечение и раскрытие преступлений в сфере незаконного оборота наркотических средств и психотропных веществ требует применения дополнительной информации, обеспечить которую могут лишь сведущие в ней лица. Институт использования специальных знаний в расследовании данной группы преступлений - это успешное направление криминалистики, но при этом, малоизученное и порождающее дискуссии в науке и на практике. Вопросы возникают уже при изучении самого понятия «специальные знания», а потому требуют более детального изучения. В связи с этим, в данной работе проанализированы различные точки зрения касательно понятия «специальные знания», изучена процессуальная сущность рассматриваемого термина на примере законодательства зарубежных стран, сделаны обоснованные выводы по данному вопросу.

Ключевые слова: специальные знания, юридические знания, криминалистические знания, сведущие лица, специалист, эксперт.

\section{Abstract}

The growth of criminal criminality in the Russian Federation is, today, a progressive phenomenon that requires a certain mechanism of counteraction, which is expressed in the mobilization of all forces and resources on the part of law enforcement and auxiliary bodies. The detection, suppression and disclosure of crimes in the field of illicit trafficking in narcotic drugs and psychotropic substances requires the use of additional information, which can only be provided by persons who are knowledgeable in it. The institute for the use of special knowledge in the investigation of this group of crimes is a successful area of criminology, but at the same time, it is poorly studied and generates discussions in science and in practice. Questions arise already when studying the very concept of "special knowledge", and therefore 
require a more detailed study. In this regard, this paper analyzes various points of view regarding the concept of "special knowledge", analyzes the procedural essence of the term in question on the example of the legislation of foreign countries, and makes reasonable conclusions on this issue.

Keywords: special knowledge, legal knowledge, forensic knowledge, knowledgeable persons, specialist, expert.

Невозможно не отметить, что состояние современного общества характеризуется, на сегодняшний день, двумя тенденциями. О первой можно говорить, как о прогрессе, поскольку уровень экономической, социальной, политической и духовной жизни довольно высок, динамичен и усовершенствован, что позволяет говорить о положительной динамике развития состояния отечественного государства. Однако, вторая тенденция характеризуется лишь регрессом, поскольку затрагивает преступную сторону общественного развития. Это связано с криминализацией населения, показатель которой растёт, как правило, за счёт процесса наркотизации. Общая причина указанного явления - наркомания, a её результат - рост наркопреступности.

Незаконный наркобизнес - это участившаяся тенденция не только современного российского общества, но и зарубежья, основной проблемой которой является её латентность. Борьба с криминальным наркомиром требует мобилизации сил, средств, методов и методик со стороны правоохранительных органов, поскольку представляет реальную угрозу отечественному государству. Однако процесс выявления, пресечения, расследования и раскрытия преступлений в сфере нелегального наркобизнеса, как показывает практика, - явление сложное и трудоёмкое, а потому требует привлечения специальных знаний.

Участие сведущих лиц в процессе расследования - залог успешного раскрытия и расследования наркопреступлений. Институт использования специальных знаний привлекает внимание учёных и практиков вот уже не один десяток лет, порождая между ними споры и противоречия, истоки которых кроются в самом понятии рассматриваемого явления.

Мнения о том, что специальные знания представляют собой приобретённый в процессе профессиональной подготовки сведущего лица набор теоретических и практических знаний и опыта в области науки, техники, искусства или ремесла, нацеленные на раскрытие, расследование и предупреждение преступлений, придерживаются Е.П. Ищенко и А.А. Топорков [1, С. 460].

А.И. Попов, понимая под специальными знаниями знания неправового характера в различных областях деятельности, указывает на их использование участниками со стороны обвинения, защиты и судом в целях выявления обстоятельств, подлежащих доказыванию и имеющих значение по уголовному делу [2, С. 9].

Невозможно не согласиться с мнением В.Д. Зеленского и Г.М. Меретукова [3, С. 343] по этому поводу, поскольку, по мнению автора данной работы, ими было дано полноценное определение понятию «специальные знания». Учёные раскрывают данный термин через систему неправовых знаний из различных областей человеческой деятельности, приобретённых в процессе высшего профессионального образования по конкретной специальности, использование которых нацелено на установление сторонами уголовного судопроизводства и судом обстоятельств, подлежащих доказыванию по конкретному делу, в порядке, предусмотренном уголовнопроцессуальным законодательством Российской Федерации.

Актуальную проблему, преобладающую вокруг понятия «специальные знания», составляет их отождествление с «криминалистическими знаниями». Уголовнопроцессуальный кодекс Российской Федерации (далее - УПК РФ) [4] в статье 58 понимает под специалистом обладающее специальными знаниями лицо, привлечение 
которого к участию в процессуальных действиях нацелено на оказание содействия в обнаружении, закреплении и изъятии предметов и документов, применении технических средств в исследовании материалов уголовного дела, для постановки вопросов эксперту, а также для разъяснения сторонам и суду вопросов, входящих в его профессиональную компетенцию. Тем самым, законодатель вложил в функциональный аппарат специалиста криминалистический подтекст, указав на получение сведений посредством производства действий по собиранию, поиску и использованию юридически значимой информации.

В свою очередь, представляется возможным отметить, что автор не разделяет указанную позицию и не отождествляет данные правовые категории. По его мнению, их соотношение допустимо в качестве общего и частного, где специальные знания применимы к профессиональной деятельности конкретного участника расследования и могут выходить за рамки юридического познания, а криминалистические непосредственно юридические знания, относящиеся ко всему процессу расследования и формирующие, при этом, собирательную картину всего изученного.

Анализируя вышесказанное, целесообразно отметить, что законодатель не счёл нужным закрепить в нормах УПК РФ легитимное определение понятию «специальные знания». В связи с этим, автор приходит к выводу о наличии серьёзного пробела современного уголовно-процессуального законодательства, что является источником проблем и препятствий в процессе расследования преступлений.

И все же указанный термин лишь между строк можно усмотреть в нормах УПК РФ. Так, например, согласно ст. 57 УПК РФ под экспертом понимают лицо, обладающее специальными знаниями и назначенное в порядке для производства судебной экспертизы и дачи заключения. Не раскрывает сущность понятия «специальные знания» и Федеральный закон от 31.05.2001 № 73-Ф3 «О государственной судебно - экспертной деятельности в Российской Федерации»[5] (далее - № 73-Ф3), в статье 2 которого говорится, что основная задача государственной судебно-экспертной деятельности - это оказание содействия органам расследования и суду в установлении обстоятельств, подлежащих доказыванию по конкретному делу, посредством разрешения вопросов, требующих специальных знаний в области науки, техники, искусства или ремесла.

В то же время, законодатель стран ближнего зарубежья норматизировал понятие «специальные знания», под которыми Уголовно-процессуальный кодекс Республики Казахстан, к примеру, в пункте 5 статьи 7[6] понимает знания, неизвестные общественности, приобретённые лицом в ходе профессионального обучения либо практической деятельности и используемые для решения задач уголовного судопроизводства.

Таким образом, подводя итог всестороннему теоретическому и практическому анализу, проведённому на основании норм законодательства и научных подходов, автором данного исследования предлагается внесение изменений и дополнений в статью 5 УПК РФ и в ст. 6 № 73-Ф3 следующего определения понятия «специальные знания»: «система сведений, знаний, умений и навыков, а также опыта работылица, полученные в процессе формирования судебно-экспертной профессиональной деятельности и сообщаемые им с целью установления обстоятельств, подлежащих доказыванию и имеющих значение по уголовному делу».

В то же время, представляется возможным, на наш взгляд, законодательно дополнить норму 1 Федерального закона от 08.01.1998 № 3-Ф3 «О наркотических средствах и психотропных веществах»[7] определением «специальные знания, используемые в сфере незаконного оборота наркотических средств и психотропных веществ» следующего содержания: «приобретённые в ходе формирования профессиональной или иной подготовки, опыта и навыков сведения, применяемые в процессуальных и непроцессуальных формах и используемые в целях установления 
обстоятельств, имеющих значение для уголовных дел о преступлениях в сфере незаконного оборота наркотических средств и психотропных веществ».

$$
* * *
$$

1. Ищенко Е.П., Топорков А.А. Криминалистика: Учебник. - 2-е издание. - М.: Юридическая фирма «КОНТРАКТ», ИНФРА-М, 2010. - С. 460.

2. Попов А.И. Актуальные проблемы использования специальных знаний эксперта и специалиста в разрешении конфликтов и конфликтных ситуаций в ходе предварительного расследования// Автореф. дис. ...канд. юрид. наук. Калиниград, 2009. - С.9.

3. Криминалистика: учебник / под ред. д.ю.н., профессора В.Д. Зеленского и д.ю.н., профессора Г.М. Меретукова - СПб, Издательство «Юридический центр», 2015. - С. 343.

4. Уголовно-процессуальный кодекс Российской Федерации от 18.12.2001 № 174-Ф3 (ред. от 24.02.2021) // Собрание законодательства РФ, 24.12.2001, № 52 (ч. І), ст. 4921.

5. Федеральный закон от 31.05.2001 № 73-Ф3 (ред. от 26.07.2019) «О государственной судебно экспертной деятельности в Российской Федерации» // Собрание законодательства РФ, 04.06.2001, № 23, ст. 2291.

6. Уголовно-процессуальный кодекс Республики Казахстан от 4 июля 2014 года № 231-V (с изменениями и дополнениями по состоянию на 02.01.2021г.) // Ведомости Парламента Республики Казахстан, август 2014, № 15-II (2664-II), ст. 88.

7. Федеральный закон от 08.01.1998 № 3-Ф3 (ред. от 08.12.2020) «О наркотических средствах и психотропных веществах» // Собрание законодательства РФ, 12.01.1998, № 2, ст. 219.

\section{Бокарева А.М., Удалов Д.Э. \\ Вопросы правовой регламентации деятельности приемной комиссии образовательной организации}

ГАОУ ВО города Москвы «Московский государственный университет спорта и туризма»

(Россия, Москва)

doi: $10.18411 / 1 j-07-2021-76$

\section{Аннотация}

В статье рассматриваются вопросы деятельности приемной комиссии образовательной организации высшего образования. Дается организационно-правовая характеристика, и определяются принципы деятельности такого структурного подразделения образовательной организации, как приемная комиссии. Анализируются положения нормативно-правовых и локальных актов, устанавливающих порядок приема на обучение в образовательную организацию.

Ключевые слова: образование, образовательная организация, приемная комиссия, функции образовательной организации, прием на обучение, правовое регулирование, образовательный процесс.

\section{Abstract}

The article discusses the issues of the activities of the admissions committee of the educational organization of higher education. The organizational and legal characteristic is given and the principles of the activity of such a structural unit of an educational organization as a selection committee are determined. The article analyzes the provisions of regulatory and local acts that establish the procedure for admission to training in an educational organization.

Keywords: education, educational organization, admissions committee, functions of an educational organization, admission to training, legal regulation, educational process.

Важным и актуальным элементом развития современного общества выступает институт образования, формирующий и подготавливающий к будущей жизни и профессионально деятельности подрастающее поколение. 